DOI: https://doi.org/10.3126/njdrs.v16i0.31574

\title{
Role of Rural Development Bank in Women Empowerment: A Poverty Alleviation Perspective
}

\author{
Sirjana Kafle \\ National Consultant, Technical and Vocational Education related Project Jointly Operating by \\ Shinshu University and JICA \\ Email for correspondence: sirjanakafle@gmail.com
}

\begin{abstract}
The study seeks to explain role of Rural Development Bank (RDB) for empowering women from poverty alleviation perspective. More so, this study was conducted in Shankarnagar located in Rupendehi District. Under quantitative case study methodology, necessary data are collected from 120 respondents selected randomly. The results show that Shankarnagar area office of RDB has played remarkable role in reducing poverty in the study area. The social and financial programmes implemented this bank has helped to alleviate poverty in some extent. It has also contributed to increase family income, self employment opportunities, better health and hygiene, better living standard, saving and credit activities and access to quality child education. Hence, better to make further social/financial plans/programmes for reducing poverty in general and empowering women in particular.
\end{abstract}

Key words: Rural Development Bank, poverty, women, women empowerment

\section{Introduction}

Survey and census authority has proved that, Nepal is the one of the poor and least developed country in the world with only US\$ 859 per capita income and exhibits huge poverty and underdevelopment. The economic growth of the country measured by GDP is 2.3 percent per year in the year 2019. Nearly one fourth of the population (25.2\%) lives below the poverty line as per the World Bank's report. The preliminary estimate of population growth rate is 1.4, (CBS, 2011). More than 74 percent of the people are depended to agriculture sector. About 80 percent of the rural poor are either self - employed in agriculture as agriculture labor.

The course of poverty are multidimensional and related to socioeconomic and structural factors which is caused by lack of economic resources for the growing population and very slow rate of national economic growth with political instability. So as to reduce the massive poverty the late seventies as after sixth five year plan, the poverty alleviation approach was integrated in to the country's mainstream financial system, recognizing the microfinance as an official poverty alleviation program. This sector gained further momentum after restoration of democracy in 1991 with the establishment of Grameen Bikas Bank (GBBs) in the five development region since that period; other different forms of MFIs have been set up. The Nepalese microfinance sector currently comprises a wide verity of models such as cooperatives, the private and the government-owned GBB/ replications government supported microfinance programs and authorized Financial Intermediary Non-Government Organization (FINGOs). 
The microfinance system initially emerged in (1970) as social innovator began to offer financial services to the working poor those who were previously considered "unbankable" because of their lack of collateral. The main faces of microfinance institution (MFIs) is to expand the micro loans to support economic activities of the poor encompassing a range of financial services such as loans, saving and Insurance to help those people with the purpose of poverty reduction. Microfinance though not a panacea has proven to be a powerful tool for poverty reduction during the last three decades. It is one of the development tools to be financially self sustaining. Microfinance has recently become a favorite intervention for development institutions, due to its unique potential for poverty alleviation and financial sustainability.

Microfinance has changes the living standard of the people revitalized communities in the world's poorest and also the richest countries. It helps the poor and services are mare resilient and better able to deal with everyday demands. Microfinance involved over the period as an economic development approach intended to benefit low-income men and women. The main objective of microfinance is to help for poverty reduction by providing the sustainable access to finance services to poor and low income household through microfinance. It is provision of a broad range of financial services to the poor people. Access to credit and saving promote livelihood opportunities, access to insurance product enables the poor to face financial shocks (NRB, 2060, p. 19).

The term 'microfinance' was first set up in the form of Grameen Bank in 1976 by Bangladeshi Professor Mohammad Yunus as a pilot group of micro loan, lending scheme for landless people of the Bangladesh. The Grammeen Bank which now services more than 7 million clients and it has model for many all over the world. The award in the year 2006 of Nobel Prize to professor M. Yunus and his Grameen Bank of Bangladesh, has directed the world attention to the phenomenon of microfinance which professor Yunus and his bank have pioneered. He started with a few pounds upwards which was used to income generating activities such as, buying rice to husk and sell or to protect a borrower from having to pay expensive rates to money lenders for essential needs such as house repairing, wedding and funerals.

Microfinance has good stride in Nepal. It gained momentum during the last one or half decades starting in early 1990 as a result of initiatives taken by social workers to start microfinance services through NGOs supported by Nepal Rastra Bank regulatory framework. Some of the microfinance NGOs has transformed themselves into microfinance bank. Nirdhan is the pioneer NGO to start microfinance and has transformed itself successfully into a microfinance bank, named as Nirdhan Utthan Bank, the leading microfinance institution in Nepal. By now the microfinance industry has achieved successes in providing services to more than one third of Nepalese poor. In Nepal, microfinance is stated to have started on Chaitra 20, 2013 B.S. with registration as 1st Co-operatives in Rapti Doon area of Chitwan District- Bhakhan Credit Co-operative Ltd. Nepal government and Nepal Rastra Bank initiated targeted credit program as important element of the poverty alleviation strategy in mid 1970s. Small Farmer Development Program (SFDP) and Priority Sector Credit Program (PSCP) was the main program of such nature. Both these programs aimed at improving socio-economic status of the rural poor. 
Grameen Bikas Bank was introduced in Nepal during 1990's by the Central Bank, establishing in five rural regional development banks, one in each development region. Nirdhan and Centre for Selfhelp Development (CSD) were two NGO initiating Gremeen Replication in the private sector. The other prominent MFIs-NGOs replicating Grameen in Nepal, are Chhimek, Depose and NRDSC, with the initiation of Nirdhan to promote Nirdhan Uthan Bank. Other MFI-NGO also promoted microfinance development banks like swabalamban bikas bank, Diprose Bikas Bank and chhimek bikas bank. The five regional level Grameen Banks have merged and became a National Microfinance Bank named Nepal Grameen Bikas Bank Ltd in 2014 through a joint collaboration of Government of Nepal, NRB, Commercial Banks, Group members and other institutions to serve poor and deprived people of the rural sector of Nepal, modeled on the Grameen Bank.

The mission of the Nepal Grameen Bank is to generate self employment through micro credit to the rural poverty at their door step to reduce poverty level of Nepal. It provides saving and loans services to the low income clients, using a Grameen Bank Methodology. It serves 1 lakh 85 thousand members through 186 branches in 52 districts located in the hill and Terai regions of Nepal. The Bank is working with the Area approach to the target group and provide collateral free loan on group guarantee following the Grameen Model. Bank has the vision to be 'an excellent micro finance bank to uplift the socio-economic conditions of the rural poor. It has also social mission, designed and developed to uplift the capacity and to create income and generate self-employment to their potentialities for the rural poor at their villages.

\section{Review of Foundational Works}

Many sociologist and economist explain connection between and among financial activities, poverty alleviation and women empowerment. The world Book Encyclopedia (1996) defines, poverty is the state or fact of being in want. People are poor if they lack enough income and resources to be adequately by the accepted living standards of their community Standards may vary greatly according to time and place. Kunwar (2003) has vividly depicted the cause of poverty prevalent in the country. More than 85 percent of the population of Nepal lives in rural areas where poverty is wide spread along with social discrimination between the haves and has not. It is known fact that agriculture is the main source of income in rural areas and the link between poverty and low productivity of agriculture is very close. The author has rightly pointed out to overcome the country's problems of poverty, corruption and bad governance is through the effective formulation and implementation of groups or organization, skills and micro-credit popularly known in Nepali term as 3 SAs (Samuha, Seep, and Snao-punji) at the local level.

Economic Review of NRB 2005, Nepal is the least development country with a per capita income $\$ 240$. The population below poverty line is 44.6 percent, in which the rural poverty is over and above the urban in percentage terms. In total, about 10 percent of the population live in the urban area where the population living below the poverty line is 17.8 percent; in the remaining 90 percent residing in the rural areas, 46.6 percent of them are living below the poverty line. Ministry of Finance (2004) analyzed poverty from human and social dimension that transcends the traditional belief that poverty appears due to the sole lack of economic resources and income, is on the rise.

The conventional definition of poverty has now been gradually broadened and widened since the connotation goes behind the implication of inadequate level of income to sustain the life. 
Now, it also includes various human dimensional aspects like illiteracy, early death, child marriage, malnutrition, sickness and so on. It is, therefore, realized that poverty is the outcome of social, political, and cultural ambiance. Although poverty is divided into two categories - absolute and relative- the former deserves more attention for analytical point of view. A poverty line is hypothesized to measure the absolute poverty. The proportion of population living below this line shows the extent of poverty. The recent estimate done by the National Planning Commission (NPC) in Poverty Reduction Strategy Paper (PRSP) is 38 percent. It is little less than 42 percent estimated by the Nepal Living Standard Survey (NLSS) conducted in 1996. Since more than 90 percent of the country's population lives in rural areas, the nature is more intense and severe in the villages of the hilly regions of the Mid and Far Western Development Regions.

Overall, poverty has become the multidimensional fact of life of the Nepalese people. The Nepal Living Standard Survey (NLSS) (1996) has estimated annual per capita income of Rs. 4,404/- to meet the expenses on daily minimum average of 2,124 calories for food and other non-food requirements. Considering the inflation level, the income at the current prices of 2001 turned out to be Rs. 6,100/- and according, 42 percent of the people were estimated to be living below the poverty line in Nepal. According to the NLSS (1996), 44.0 percent of the rural population was estimated to be living below the poverty line whereas this population was 23.0 percent in urban areas. Only 4.0 percent of the rural population was below the poverty line in Kathmandu valley. Likewise, poverty level was up to 53 percent in the Terai districts of Far Western Development Region whereas it was up to 56 percent in the hilly districts of the Mid-Western Development Region. Poverty level was as high as 72 percent in those districts of the hills and high hills areas of the Far-Western Development region. The NLSS has overall estimated the incidence of poverty to be 40 percent, the depth/inequality ration 12.1 percent and the severity 5 percent. The PRSP has not only acknowledged the income based poverty but also the indicators of human poverty like literacy, birth/death rates, and access to the basic social and economic infrastructures, with particular focus on the deprived classes, women and remote areas.

The Rural Household Survey (2001) has shown a slide decrease on the poverty level during the period (1996-2001). The reasons apparently cited are: annual increase in GDP by 4.8 percent, annual increase in agriculture growth rate by 3.7 percent and 30 percent annual increase in remittances in the country. According to the Tenth Plan, the overriding objective of the Tenth Plan is to alleviate poverty by appropriately addressing the income-based poverty to 33 percent under the normal growth scenario (4.3\%) and to 30 percent under the expected high scenario (6.2\%) and has devised polices, strategies and programme accordingly. In the similar vein, other dimensions adopted by the plan are human and social aspects having indicators like life expectancy, child mortality, maternal mortality primary school enrollment and literacy (in terms of gender, caste and regions) along with quantifiable goals and specific activities on social and other economic sectors.

The Tenth plan has shown the commitment to implement its four pillars through the means of MTEP and IAP: (i) achieving high, broad-base and sustainable economic growth; (ii) improving the quality and availability of social and economic services, and infrastructure, (iii) ensuring social and economic inclusion of the poor, marginalize and vulnerable groups, and (iv) promoting good governance. A significant percent of people, both men and women, poor and rich and urban and rural society feels that in Nepal economic liberalization has not been able to reduce poverty. Reasons for 
government's failure are; rising inflation, lack of cheap credit, non affordability of agricultural inputs, unorganized and small markets, rampart corruption, weak governance and total failure of public work programmes to credit short term policy and generate and long term sustainable and social benefit for targeted communities (WB, 1998).

\section{Research Gaps}

In our country, women are as the traditional producers and managers of the domestic and subsistence sector. Our development policy has been centre-oriented even though major proportion of the population live in villages. Employment and income opportunities are confined only to cities. Most of the people especially in Nepal are not facilitated by government efforts; it is due to their unconsciousness towards government activities. The extension services do not reach to the peasant because of the poverty. They are so poor that they cannot afford to new techniques and also could not get credit from banks due to their lack of good securities.

Women development is a major component in social dimensions of development. Social and legal discrimination, gender disparity, poor socio- economic and demographic status of the women put them in relatively more deprived group in Nepal. Since women influence the well being of children and other family members, disparity in access to economic resources and social services make development efforts insignificant. Because of the low participation in education and more domestic work assigned to them, women's earnings is substantially lower than men's one.

In other words, more work, frequent child birth, lower medical facilities cause the welfare of women substantially fellow that of males in families at the same income level. Women employed in the industrial sector are mostly semi-skilled or unskilled and mainly concentrated on activities such as spinning, weaving, knitting, food processing and tailoring. Most rural female of are 19 years and above are married. The early marriage, lack of education, poor health and malnutrition has led to the high maternal rate as well as high infant mortality rate in Nepal. Thus poverty, illiteracy and socio-economic backwardness have made women more vulnerable to deprivation. The philosophy of cutting public expenditure and leaving everything at the mercy of the market is not thus appropriate if we consider addressing the welfare of women. To uplift the life standard of women by alleviating their poverty, the government has set up Nepal Grameen Bikas Bank Ltd. The bank is basically rural bank that offer a comprehensive package consisting of loan facility. Literacy programmes, general health and sanitation to landless and poorest of the poor people in the rural areas in order to uplift their socio-economic condition and general living standard. In this context, women empowerment through financial activities in general and through rural development bank must be highlighted by academicians and professional researchers. Hence this study tried to explain role of Rural Development Bank (Grameen Bikash Bank) in the process of empowering women living around Shankarnagar socially and economically.

\section{Objectives}

- To compare and contrast living standard of women before and after interventions of Rural Development Bank (RDB) in this particular area.

- To explain changing socio-economic role of women in this particular area. 


\section{Methodology}

This study applied quantitative case study method in which both primary and secondary nature of data are collected according to research issues. The primary data are collected from 120 respondents selected randomly. Likewise, secondary data are collected through published books, articles as well as published and unpublished reports. All the data are analyzed descriptively and illustratively.

\section{Result and Discussion}

The study found transformative role of Rural Development Bank, Shankarnagar are office on poverty alleviation. Women are becoming more empowered after the interventions of this bank and plying social and economic role in household and social levels. Owing to that family income of the respondents have been increased and investing for child education and also for better living standard. More so, the major findings are listed below:

- In Shankarnagar Area Office, 120 sample respondents have borrowed NRs. 1, 29, 00,000 in the study period. Out of them, 42 borrowers have borrowed NRs. 150000, 54 borrowers have borrowed 100000 and 24 borrowers have borrowed NRs. 50000 loan. These borrowers are running in different phase of investment. 12 borrowers are running in 3rd phase and 6 borrowers in 5 th phase. Similarly 6, 42 and 54 borrowers are running in 6th, 7th and above 10th phase respectively. This shows that there is high demand for loan amount in the rural areas but there is not yet enough supply of the loan amount.

- Loan Repayment percentage is 100 among the respondent women which is positive for future sustainability of NGBBL, Similarly, more than 75 percent borrowers feel the interest rate weekly/ fortnightly/monthly repayment system is suitable for them.

- Before NGBBL's intervention, more than 66.67 percent of the total members was engaged in agricultural and wage labour and only less than 33.33 percent was in non-agricultural sector. After NGBBL's intervention, more than 59.17 percent of the total borrowers are engaged in nonagricultural sector. This fact shows that the loan amount borrowed from NGBBL has significant diverted the rural women from traditional sector to non-traditional sector.

- There has been satisfactory increase in employment and entrepreneurship talent of the rural women because every borrowers has started new business i.e. off-farm business.

- Before borrowing more than 40.83 percent of the total members had income amount of less than NRs. 7500 per month whereas after NGBBL intervention, only 21.66 percent has remained in this class. Similarly before borrowing, there was about 43.34 percent who earn more than NRs. 7500 per month whereas it has been increased to 78.34 percent after being the number of NGBBL. This fact proves that there has been a significant increase in the income level of the borrowers.

- Saving rate of the borrowers is also increased after the intervention of the bank which is positive sign for development. Similarly, utilization of the saving is also satisfactory. Most of the women utilize saving for productive activities.

- Consumption pattern, sheltering and clothing is significantly improved which implies the living standard of the rural poor is uplifted.

- Homeless people are purchasing a segment of land for settling in limited scale.

- Economic dependency has been gradually shifted from male to female.

- Condition of education, child education health and sanitation, family planning, clean drinking 
water, environment etc. are drastically changed after the intervention of NGBBL. Similarly, Socioeconomic and political status of the borrowers have been significantly increased.

\section{Conclusion}

Gramin bank is basically rural bank launched for poverty reduction through women's participation in social and economic activities. The main objectives of the bank are to introduce and institutionalize a non-traditional banking system in rural areas which would provide credit facilities under special terms and conditions. The project attempts to serve those rural people who are not covered by the traditional banking system. The living standard of the members has been greatly improved after the interventions of GBB programme. Availability of safe drinking water, use of toilets and use of modern medical facilities has been increased. Other social condition such as education facilities has been increased. Other social condition such as education, clothing, sanitation, environment and housing situation have been improved. Overall, NGBBL has played a significant role in alleviating poverty or rural women in the study area. The bank's lending activities have contributed to increase employment, land holding, housing income, saving and consumption which constitute the major indicators in changing poverty situation.

\section{References}

Agricultural Development Bank (2003). Annual report 2058/59. Kathmandu: Author.

Tsegaye, A. (2009). Statistical analysis of the preference of micro finance institutions in Ethiopian case. Saving and Development, 2(33), University of Bergamo, Italy.

Armendariz, B., \& Morduch, J. (2007). The economics of microfinance. New Delhi: Prentice Hall.

Asian Development Bank (ADB). (2003). Key indicators: Education for global participation, (Special Chapter), Manila: Author.

Bashyal, R. (2008). Microfinance: Access to finance for Nepal's rural poor. Kathmandu: Institute for Integrated Development Studies (IIDS).

Bashyal, R. (2008). Prevalent microlending methodologies in the LDCs. The Economic Journal of Nepal, 31(2). CEDECON-TU.

Canter for Microfinance (CMF). (2002). Microfinance summit report, 2002. Bhatbhateni, Kathmandu: Microfinance Summit Secretariat.

CECI (2008). Microfinancing towards empowerment of disadvantage group in Nepal: Inovation and practice. Kathmandu: Canedian Centre for International Studies and Cooperation.

Central Bureau of Statistics (CBS). (2001). Population census, national report. Thapathali, Kathmandu: Government of Nepal.

Central Bureau of Statistics (CBS). (2005). Summary results on poverty analysis from Nepal living standards survey 2003/04. Thapathali, Kathmandu: Government of Nepal.

Fujukara, M. (2004). Social, economic and cultural change in Nepal. Chicago University, Japan.

Gulli, H., \& Berger, M. (1999). Microfinance and poverty reduction: Evidence from Latin America. Small Enterprise Development, 10(3), 16-28.

Helms, B. C. (2006). Access for all. Washington DC: World Bank.

Hulme D., \& Mosley P. (1996). Finance against poverty. London: Author.

INAFI, SAP Nepal (2005). Impact of Microcredit Services on Poverty Reduction in Nepal. Kathmandu: Author.

Nepalese Journal of Development and Rural Studies, Volume 16, 2019 
Kono, H., \& Takahashi, K. (2010). Micro finance revolution: Its effects, innovation and challenges. The Institute of Developing Economies IDE-JETEO, 48(1).

Majarino, F. (2007). An evaluation of the rural microfinance development centre (RMDC) as a wholesale lending institution in Nepal (Working Paper Services No. 8). Kathmandu: Asian Development Bank.

Maskey, N. M. (2011). The transformative journey of Pashchimanchal Grameen Bikasank, PGBB. Butwal Rupandehi: Author.

Mathema, V. R. (2008). Microfinance in Nepal. Kathmandu: Author.

Ministry of Finance (MoF). (2010). Economic survey 2010/11. Kathmandu: Government of Nepal.

Nepal Rastra Bank (1996). Forty Years of Nepal Rastra Bank, 1956-1996, Kathmandu, Nepal.

Nepal Rastra Bank (2007). A glimpse of Nepal's microeconomic situation. Baluwatar, Kathmandu: Microcredit Department.

Nepal Rastra Bank (2019). Current macro economic and financial situation- Nepal, 2076/2077.

NRB (2009). Nepalese financial system: Growth and challenges. Baluwatar, Kathmandu: Author.

Panta, R. (2009). Microfinance access and uses (Nepal Rastra Bank Samachar). Baluwatar, Kathmandu: Author.

Pitt, M., \& Khandker, S. (1998). The impact of group based credit programs on poor households in Bangladesh: Does the gender of participants matters? Journal of Political Economy, 106, 958-996.

Pradhan. U. L. (2008). Youth and children inclusiveness in microfinance and livelihood approach (Microfinance Submit Report 2008). Kathmandu: Author.

RMDC (2008). Impact of micro finance program on socio-economic status of the ultimate beneficiaries. Kathmandu: Author.

Sen, A. (1982). Poverty and famines: An essay on entitlement and deprivation. London: Oxford University Press.

Senanayake, S. M. P., \& Permaratne, S. P. (2006). Microfinance for accelerated development. Italy: University of Bergamo.

Sharma, M. L., \& Thapa, P. (2008). Women in rural micro finance program in the western Hill of Nepal. Baluwatar Kathmandu: CECI.

Simanowitz, A., \& Walter, A. (2002). Reaching the poorest while building financially self-sufficient institutions and showing improvement in the lives of the poorest women and their families. In S. D. Harris (Ed.), Pathways Out of Poverty: Innovations In Microfinance For The Poorest Families (1-74). Blue Hills, U. S. A.: Kumarian Press, Inc.

UNDP (2006). Reading in human development. Kathmandu: Author.

Wheele Kenneth, D. V., \& Tyler, W. (2006). Microfinance impact assessment: Evidence from a development program in Honduras. Saving and Development, 2(31). Italy: University of Bergamo.

World Bank (1997). Microfinance hand book. New York. Author.

World Bank (1998). Bangladesh: Poverty alleviation microfinance project (Staff Appraisal Report). Washington, DC: South Asia Region, Private Sector. Development and Finance Division.

World Bank (2002). Poverty and vulnerability in South Asia, Washington DC: Author. Yunus, M. (1993). Overcoming poverty through credit: The Asian experience in replicating the Grameen Bank Approach. Dhaka, Bangladesh: Author. 